\title{
Companies' Perspectives on Factors Affecting Consumer Satisfaction in Fast-Food Restaurant using Fuzzy AHP
}

\author{
Suzanawati Abu Hasan ${ }^{1 *}$, Nur Aqilah Hassan ${ }^{2}$, Teoh Yeong $\mathrm{Kin}^{3}$, Norpah Mahat ${ }^{4}$, Anas Fathul Ariffin ${ }^{5}$, \\ 1,2,3,4,5 Faculty of Computer and Mathematic Sciences, \\ Universiti Teknologi MARA Perlis Branch, Arau Campus, 02600 Arau, Perlis, Malaysia \\ Corresponding author: *suzan540@uitm.edu.my \\ Received Date: 13 August 2021 \\ Accepted Date: 30 August 2021 \\ Published Date: 13 September 2021
}

\section{HIGHLIGHTS}

- This study concentrates on the factors that satisfied customers' demands for the restaurants to gain customers' loyalty.

- The pricing, quality of food, quality of service, and atmosphere of the selected fast-food restaurants all influence customers' impressions.

- This study needs to help them identify the factors that affect customer satisfaction towards their fastfood restaurant to prevent them from losing their customers and avoid financial losses.

\begin{abstract}
In today's world, the fast-food restaurant has become a popular sort of eatery. The fast-food industry's expansion is always changing in response to customer requests in order to meet their needs. As a result, clients have a wide range of fast-food restaurants to choose from in order to satiate their hunger. Clients' contentment with restaurants will influence not just the image of the establishments, but also the services offered by their employees as they strive to entertain and deliver the best possible service to their paying customers. However, the competition between the restaurants have caused certain restaurants to gain lower profits as the customers' satisfaction is not fulfilled for certain factors. Price, food quality, service quality, restaurant atmosphere, promotion, customer expectations, and brand are all elements to consider. This study was conducted to analyse the importance of factors in customer satisfaction in a fast-food restaurant in Perlis. In this study, the method applied is the Fuzzy Analytical Hierarchy Process (AHP) to rank the factors that have a high impact on customer satisfaction. The selected fast-food restaurants were McDonald (McD), Kentucky Fried Chicken (KFC), Pizza Hut, Domino's Pizza, Marrybrown, and Subway. The primary data collected through the questionnaire were analysed by experts, the manager of the fast-food restaurant selected. The findings show that in a fast-food restaurant, the quality of service with 0.2188 of normalized weight is the most important factor in customer satisfaction, and the price with 0.0436 of normalized weight is the least significant. The role of the manager and the staffs were thus evidently more important in customer satisfaction than the price offered.
\end{abstract}

Keywords: Fuzzy AHP, customer satisfaction, fast-food restaurant, price, quality offood, quality of service, atmosphere of the restaurant, promotion, customer expectation, brand 


\section{INTRODUCTION}

In the current marketing trend, all businesses have competitors include the fast-food industry, and in some cases, industry competition is so fierce that companies have to fight for the business of potential customers. The expansion of the fast-food industry rapidly changes according to the demands of the customers to satisfy their needs. Fast-food industry failure or success is based on factors such as promotion, quality of service, customer expectations, brand, physical environment, price, and product taste (Khan et al., 2013). Customers' satisfaction with the restaurants will influence not only the image but also the services provided by the staff of said fast-food eateries as they seek to entertain and give the best possible service to their paying customers. Customer satisfaction is also seen as affecting the repurchase desires and actions, resulting in potential revenue and profits for a company (Qin \& Prybutok, 2009). Management and staff must evaluate customer satisfaction elements in order to keep their customers happy.

Instead of investing more resources to gain potential new consumers, companies attempt to gain a high level of customer loyalty and keep their current clients. The producers and advertisers, therefore, try to keep their consumers happy so that they would stay loyal to the group and so that corporations could gain full market share (Akhtar \& Rehman, 2014).

The fast-food sector has become one of the most well-known food establishments because the food served is in line with current trends, particularly among young people who are always up-to-date on the latest fashions. Fast-food is a system that serves a large number of customers in a short time by preparing and serving food in a standardized way (Kecek \& Gurdal, 2016). Buying food from fast-food restaurants is convenient and gratifying for teenagers because the food preparation is quick, especially for those hurrying to work or class or those on a tight schedule. To meet client demand, numerous sorts of fast-food restaurants have been introduced in this era. As a result, it raises competition among fast-food establishments, preventing them from losing consumers. Aside from that, these fast-food restaurants must come up with a variety of new items or services to keep their consumers entertained and avoid financial losses. In order for a restaurant's senior management to establish client loyalty, a study must be undertaken to assist them in identifying the aspects that influence consumer satisfaction with their fast-food business.

The major data collection method was to send a questionnaire to the upper management of Perlis' fast-food restaurants. Six specialists from each fast-food establishment were chosen. As an expert, the upper management of fast-food restaurants was picked, and their comments served as the key data. The manager was chosen as an expert since a manager is constantly on the lookout for a client's behaviour, regardless of whether the consumer is satisfied or not.

Analytical Hierarchy Process (AHP) is a decision support method improved in completing the conflict via solving the solution problem, classifying them, and then organizing them into a ranked structure (Putra et al., 2018). To be successful in this study, we need to accomplish two things. Fuzzy AHP will be used to rank the elements that influence customer satisfaction in a fast-food restaurant and to examine the importance of factors in fulfilling consumers' needs.

\section{METHODOLOGY}

The primary data was gathered by sending a questionnaire to the upper management of Perlis' fast-food establishments. The survey asked about factors that influence customer happiness. The specialist were tasked with reviewing, ranking, and comparing all of the elements. This study focuses on the customers' assessment of the price, food quality, service quality, and atmosphere of a fast-food restaurant in Perlis. Fuzzy AHP was used to evaluate the data in order to determine which factor had the greatest impact on customer happiness. AHP can also be used to solve a selection of project management information systems, 
the introduction of automation into the construction process, selection of procurement for project implementation, risk assessment and risk-based ranking alternatives (Praščević \& Praščević, 2016). Saaty (1977) developed the AHP method to deal with the determination of the relative importance of criteria in multi-criteria decision-making problems (Jovčić et al., 2019). As decisions are rarely made by a single stakeholder, group decision-making by aggregating individual preferences can be significantly more reflective of real-world decision-making than AHP with a single decision-maker (Velazquez et al., 2010).

\section{Formulate Fuzzy AHP Saaty's Scale with linguistic terms}

Table 1: Linguistic Terms with Triangular Fuzzy Numbers.

\begin{tabular}{|c|c|c|}
\hline $\begin{array}{c}\text { Classic Saaty's } \\
\text { scale }\end{array}$ & Linguistic terms & $\begin{array}{c}\text { Fuzzy scale } \\
\text { (Triangular scale) }\end{array}$ \\
\hline 1 & Equally Importance & $(1,1,1)$ \\
\hline 3 & Moderate Importance & $(2,3,4)$ \\
\hline 5 & Strong Importance & $(4,5,6)$ \\
\hline 7 & Very Strong Importance & $(6,7,8)$ \\
\hline 9 & Extremely Strong Importance & $(9,9,9)$ \\
\hline 2 & & $(1,2,3)$ \\
\hline 4 & \multirow{2}{*}{ Values designed for evaluation of the } & $(3,4,5)$ \\
& so-called interphase. & $(5,6,7)$ \\
& & $(7,8,9)$ \\
\hline 8 & &
\end{tabular}

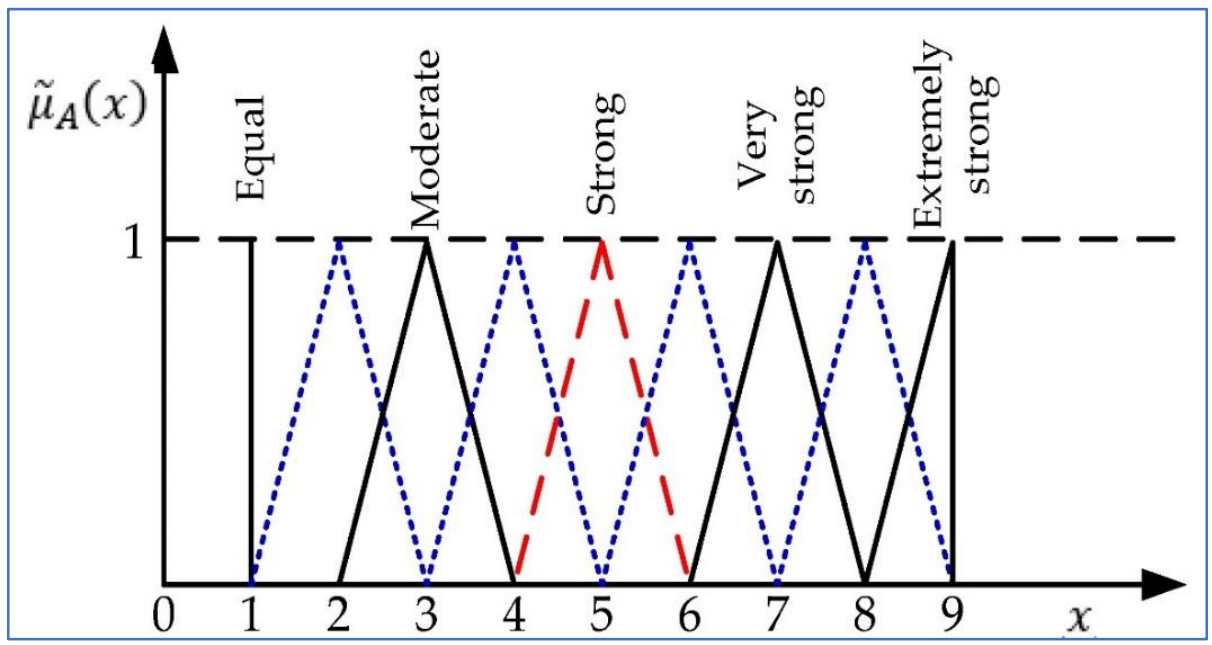

Figure 1: Triangular Fuzzy Number Membership

In the Fuzzy AHP method, the presumption is that all the parameters concerned are separate from each other. Throughout the practice, however, the relationship between parameters is typically complex, in which interdependencies can exist (Putra et al., 2018). The decision-maker employed the specified fuzzy number on the right side of the scale, according to appropriate linguistic terms. If, on the standard Saaty's scale of 7 , Factor 1 is more essential than Factor 2, then the fuzzy triangle scale will be $(6,7,8)$. In the pairwise comparison matrix of the criteria, if Factor 2 is less essential than Factor 1 on a scale of 1/7, the fuzzy triangular scale will be $(1 / 8,1 / 7,1 / 6)$. As illustrated in equation, the pairwise comparison matrix of the factors is represented as a matrix (1). 


$$
\tilde{P}=k\left[\begin{array}{cccc}
\mathrm{Z}_{11}^{k} & \mathrm{Z}_{12}^{k} & \ldots & \mathrm{Z}_{13}^{k} \\
\mathrm{Z}_{21}^{k} & \mathrm{Z}_{22}^{k} & \ldots & \mathrm{Z}_{23}^{k} \\
\ldots & \ldots & \ldots & \mathrm{Z}_{i j} \\
\mathrm{Z}_{n 1}^{k} & \mathrm{Z}_{n 2}^{k} & \ldots & \mathrm{Z}_{n n}^{k}
\end{array}\right]
$$

Equation (1) shows that the k-th decision-maker prefers the $\mathrm{i}$-th criterion over the $\mathrm{j}$-th criterion when applying fuzzy triangular numbers. The " " symbol denotes that the triangular number is being demonstrated. If there were more than one decision-maker, the priority of each decision-maker was multiplied and determined as indicated in matrix (1).

$$
\tilde{Z}_{i j}=\sum_{k=1}^{k} \frac{\tilde{Z}_{i j}^{k}}{k}
$$

\section{Pairwise Contribution Matrix}

The pairwise contribution matrix was updated according to averaged preferences, as shown in equation (3).

$$
\widetilde{P}=k\left[\begin{array}{cccc}
\mathrm{Z}_{11} & \mathrm{Z}_{12} & \ldots & \mathrm{Z}_{1 \mathrm{n}} \\
\mathrm{Z}_{21} & \mathrm{Z}_{22} & \ldots & \mathrm{Z}_{2 \mathrm{n}} \\
\ldots & \ldots & \ldots & \mathrm{Z}_{i j} \\
\mathrm{Z}_{\mathrm{n} 1} & \mathrm{Z}_{\mathrm{n} 2} & \ldots & \mathrm{Z}_{\mathrm{n} n}
\end{array}\right],
$$

where $\tilde{P}$ represents the pairwise contribution matrix. Pair-wise comparisons methods (Dotoli et al., 2020), (Kahraman et al., 2015) rely on comparing alternatives in pairs to judge which one is preferred on the basis of the chosen evaluating criteria. In this category, AHP (Analytic Hierarchy Process) is quite popular.

\section{Geometric Mean of Fuzzy Comparison Values}

Geometric mean of fuzzy comparison values by using equation (4).

$$
\begin{aligned}
& \tilde{t}_{i}=\left(\prod_{j=1}^{n} \tilde{Z}_{i j}\right)^{\frac{1}{n}}, \\
& i=1,2, \ldots, n
\end{aligned}
$$

where $\tilde{t}_{i}$ is a geometric mean of fuzzy comparison values. Each fuzzy value from a pairwise comparison matrix was multiplied with $\prod_{j=1}^{n} \tilde{Z}_{i j}$. 


\section{Weights of Criteria Using Fuzzy AHP}

The fuzzy weight for each criterion as shown in equation (5) followed by three steps.

Step 1: Find the vector summation of each $\tilde{t}_{i}$.

Step 2: Find the $(-1)$ power of the summation vector. The fuzzy triangular number is replaced to make it an increasing order.

Step 3: Multiply each $\tilde{t}_{i}$ reverse vector to find the fuzzy weight of the criterion $i\left(\tilde{W}_{i}\right)$.

$$
\tilde{W}_{I}=\tilde{t}_{i}\left(\tilde{t}_{1} \oplus \tilde{t}_{2} \oplus \tilde{t}_{3} \oplus \ldots \oplus \tilde{t}_{n}\right)^{-1}=\left\{e W_{i}, f W_{i}, g W_{i}\right\} \text {, }
$$

where $e W_{i}, f W_{i}, g W_{i}$ are obtained fuzzy triangular numbers.

\section{Defuzzification and Normalization}

The fuzzy weight of each criterion was defuzzied by using equation (6).

$$
M_{i}=\frac{e \tilde{W}_{i}+f \tilde{W}_{i}+g \tilde{W}_{i}}{3}
$$

The weight of each criterion was normalized if necessary, by implying equation (7).

$$
N_{i}=\frac{M_{i}}{\sum_{i=1}^{n} M_{i}}
$$

To find the normalize weights of the criteria, all of the methods were used. The criteria with the highest score was suggested to the decision-maker as the most important consideration based on the results. 


\section{RESULTS AND DISCUSSIONS}

Step 1: Fuzzy AHP Saaty's scale was formulated with linguistic terms. From the questionnaire obtained, the experts compared criteria that would affect customer satisfaction in the fast-food restaurant.

Table 2 Comparison of Criteria Using Saaty's Scale with Linguistic Terms.

\begin{tabular}{|c|c|c|c|c|c|c|}
\hline Factors / Criteria & $\begin{array}{c}\text { Decision- } \\
\text { maker } 1\end{array}$ & \begin{tabular}{|c|} 
Decision- \\
maker 2 \\
\end{tabular} & \begin{tabular}{|c|} 
Decision- \\
maker 3 \\
\end{tabular} & $\begin{array}{r}\text { Decision- } \\
\text { maker } 4 \\
\end{array}$ & \begin{tabular}{|c|} 
Decision- \\
maker 5 \\
\end{tabular} & $\begin{array}{r}\text { Decision- } \\
\text { maker } 6 \\
\end{array}$ \\
\hline Price & 1 & \multirow[t]{2}{*}{1} & 1 & \multirow[t]{2}{*}{1} & 1 & \multirow[t]{2}{*}{1} \\
\hline Quality of Food & $\overline{3}$ & & $\overline{9}$ & & $\overline{9}$ & \\
\hline Price & 1 & \multirow[t]{2}{*}{1} & 1 & \multirow[t]{2}{*}{1} & 1 & 1 \\
\hline Quality of Service & 4 & & $\overline{9}$ & & 9 & 9 \\
\hline Price & 1 & \multirow[t]{2}{*}{1} & 1 & 1 & 1 & \multirow[t]{2}{*}{1} \\
\hline Atmosphere restaurant & $\overline{3}$ & & 8 & 9 & $\overline{7}$ & \\
\hline Price & 1 & 1 & \multirow[t]{2}{*}{1} & 1 & 1 & \multirow[t]{2}{*}{1} \\
\hline Promotion & $\overline{6}$ & $\overline{7}$ & & 9 & 6 & \\
\hline Price & 1 & \multirow[t]{2}{*}{1} & \multirow[t]{2}{*}{1} & 1 & $\frac{1}{2}$ & \multirow[t]{2}{*}{1} \\
\hline Customer expectation & 2 & & & 9 & 7 & \\
\hline Price & 1 & \multirow[t]{2}{*}{1} & 1 & 1 & 1 & 1 \\
\hline Brand & 7 & & 7 & 9 & 9 & 9 \\
\hline Quality of Food & \multirow[t]{2}{*}{1} & \multirow[t]{2}{*}{1} & \multirow[t]{2}{*}{1} & \multirow[t]{2}{*}{1} & \multirow[t]{2}{*}{1} & \multirow[t]{2}{*}{1} \\
\hline Quality of Service & & & & & & \\
\hline Quality of Food & \multirow{2}{*}{4} & \multirow[t]{2}{*}{1} & \multirow[t]{2}{*}{7} & \multirow[t]{2}{*}{1} & \multirow[t]{2}{*}{4} & \multirow[t]{2}{*}{1} \\
\hline Atmosphere restaurant & & & & & & \\
\hline Quality of Food & \multirow[t]{2}{*}{3} & \multirow[t]{2}{*}{7} & \multirow[t]{2}{*}{7} & \multirow[t]{2}{*}{1} & \multirow[t]{2}{*}{7} & \multirow[t]{2}{*}{9} \\
\hline Promotion & & & & & & \\
\hline Quality of Food & \multirow[t]{2}{*}{1} & 7 & 1 & 1 & 9 & 1 \\
\hline Customer expectation & & & & & & \\
\hline Quality of Food & 1 & 7 & 1 & 1 & 1 & 1 \\
\hline Brand & & & & & & \\
\hline Quality of Service & 1 & 8 & 1 & 1 & 2 & 9 \\
\hline Atmosphere restaurant & & & & & & \\
\hline Quality of Service & 1 & 8 & 1 & 1 & 4 & 9 \\
\hline Promotion & 2 & & & & & \\
\hline
\end{tabular}




\begin{tabular}{|c|c|c|c|c|c|c|}
\hline Quality of Service & \multirow{2}{*}{3} & \multirow[t]{2}{*}{6} & \multirow[t]{2}{*}{1} & \multirow[t]{2}{*}{1} & \multirow[t]{2}{*}{7} & \multirow[t]{2}{*}{1} \\
\hline Customer expectation & & & & & & \\
\hline Quality of Service & \multirow[t]{2}{*}{1} & 1 & \multirow[t]{2}{*}{7} & \multirow[t]{2}{*}{1} & \multirow[t]{2}{*}{1} & \multirow[t]{2}{*}{1} \\
\hline Brand & & 8 & & & & \\
\hline Atmosphere restaurant & \multirow[t]{2}{*}{2} & \multirow[t]{2}{*}{6} & 1 & \multirow[t]{2}{*}{1} & 1 & \multirow[b]{2}{*}{9} \\
\hline Promotion & & & 6 & & 2 & \\
\hline Atmosphere restaurant & 1 & \multirow[t]{2}{*}{8} & 1 & \multirow[t]{2}{*}{1} & \multirow[t]{2}{*}{4} & \multirow[t]{2}{*}{1} \\
\hline Customer expectation & 2 & & 8 & & & \\
\hline Atmosphere restaurant & \multirow[t]{2}{*}{1} & \multirow[t]{2}{*}{1} & \multirow[t]{2}{*}{1} & \multirow[t]{2}{*}{1} & \multirow[t]{2}{*}{1} & \multirow[t]{2}{*}{1} \\
\hline Brand & & & & & & \\
\hline Promotion & \multirow[t]{2}{*}{2} & \multirow[t]{2}{*}{1} & \multirow[t]{2}{*}{1} & \multirow[t]{2}{*}{1} & \multirow[t]{2}{*}{1} & \multirow[t]{2}{*}{1} \\
\hline Customer expectation & & & & & & \\
\hline Promotion & \multirow[t]{2}{*}{1} & \multirow[t]{2}{*}{1} & \multirow[t]{2}{*}{7} & \multirow[t]{2}{*}{1} & 1 & \multirow[t]{2}{*}{1} \\
\hline Brand & & & & & 5 & \\
\hline Customer expectation & \multirow[t]{2}{*}{4} & 1 & 7 & 1 & 1 & 1 \\
\hline Brand & & 7 & & & 5 & \\
\hline
\end{tabular}

Step 2: The pairwise contribution matrix was updated according to averaged preferences.

Step 3: Geometric mean of fuzzy comparison values. The geometric mean of fuzzy comparison values was required to find the fuzzy weight for each criterion.Example of calculation in finding geometric mean for price criteria:

$$
(0.463,0.476,0.501)=\left(\begin{array}{l}
\left(1 \times \frac{11}{19} \times \frac{20}{73} \times \frac{29}{67} \times \frac{29}{69} \times \frac{47}{79} \times \frac{19}{72}\right)^{\frac{1}{7}},\left(1 \times \frac{16}{27} \times \frac{24}{85} \times \frac{33}{73} \times \frac{22}{51} \times \frac{5}{8} \times \frac{17}{63}\right)^{\frac{1}{7}}, \\
\left(1 \times \frac{18}{29} \times \frac{8}{27} \times \frac{37}{76} \times \frac{25}{56} \times \frac{5}{7} \times \frac{5}{18}\right)^{\frac{1}{7}}
\end{array}\right)
$$

Step 4: The fuzzy weight for each criterion was calculated following three sub-steps:

Step 4.1: The vector summation, $\tilde{t}$ was found.

$$
\begin{aligned}
\tilde{t} & =\left(\begin{array}{c}
(0.463+2.235+2.241+1.217+1.194+1.209+1.621) \\
(0.476+2.396+2.404+1.327+1.344+1.302+1.719) \\
(0.501+2.550+2.564+1.460+1.503+1.407+1.814)
\end{array}\right) \\
& =(10.179,10.967,11.799)
\end{aligned}
$$


Step 4.2: The (-1) power of the summation vector was calculated. The fuzzy triangular number was replaced to arrange it in increasing order.

$$
\begin{aligned}
& \frac{1}{\tilde{t}}=\left((10.179)^{-1},(10.967)^{-1},(11.799)^{-1}\right) \\
& \frac{1}{\tilde{t}}=(0.098,0.091,0.085)
\end{aligned}
$$

The value obtained needs to be in increasing order, so the value was rearranged.

$$
\begin{aligned}
& \frac{1}{\tilde{t}}=(0.098,0.091,0.085) \\
& \frac{1}{\tilde{t}}=(0.085,0.091,0.098)
\end{aligned}
$$

Table 3 The Fuzzy Weight for Each Criterion.

\begin{tabular}{|c|c|}
\hline Criteria & Geometric mean \\
\hline Price & $(0.463,0.476,0.501)$ \\
\hline Quality of food & $(2.235,2.396,2.550)$ \\
\hline Quality of service & $(2.241,2.404,2.564)$ \\
\hline Atmosphere of restaurant & $(1.217,1.327,1.460)$ \\
\hline Promotion & $(1.194,1.344,1.503)$ \\
\hline Customer expectation & $(1.209,1.302,1.407)$ \\
\hline Brand & $(1.621,1.719,1.814)$ \\
\hline Total & $(10.179,10.967,11.799)$ \\
\hline Inverse & $(0.098,0.091,0.085)$ \\
\hline Increasing order & $(0.085,0.091,0.098)$ \\
\hline
\end{tabular}

Step 4.3: Each reverse vector of $\tilde{t}$ was multiplied with the geometric mean obtained to find the fuzzy weight of each criterion. Example of calculating the fuzzy weight for price criteria is as follows:

$$
(0.039,0.043,0.049)=((0.463 \times 0.085),(0.476 \times 0.091),(0.501 \times 0.098))
$$


Table 4 Fuzzy Weight for Average Preferences.

\begin{tabular}{|c|l|l|}
\hline Criteria & $\begin{array}{c}\text { Normalized } \\
\text { weight }\end{array}$ & Rank \\
\hline Price & 0.044 & 7 \\
\hline Quality of food & 0.218 & 2 \\
\hline $\begin{array}{c}\text { Quality of } \\
\text { service }\end{array}$ & 0.219 & 1 \\
\hline $\begin{array}{c}\text { The atmosphere } \\
\text { of the restaurant }\end{array}$ & 0.122 & 5 \\
\hline Promotion & 0.123 & 4 \\
\hline $\begin{array}{c}\text { Customer } \\
\text { expectation }\end{array}$ & 0.119 & 6 \\
\hline Brand & 0.156 & 3 \\
\hline Total & 1.000 & \multicolumn{1}{|l}{} \\
\cline { 2 - 3 }
\end{tabular}

Step 5: The fuzzy weight of each criterion was defuzzified. In finding the weightage of each criterion, defuzzification of the fuzzy weightage was required using the average of the value respective to each criterion. Example of calculating the weightage of the price criteria is as follows:

$0.044=(0.039+0.043+0.049) \div 3$

Table 5 Weightage for Each Criterion

\begin{tabular}{|c|c|}
\hline Criteria & Weight \\
\hline Price & 0.044 \\
\hline Quality of food & 0.219 \\
\hline Quality of service & 0.220 \\
\hline Atmosphere of restaurant & 0.123 \\
\hline Promotion & 0.124 \\
\hline Customer expectation & 0.120 \\
\hline Brand & 0.157 \\
\hline Total & 1.007 \\
\hline
\end{tabular}


Step 6: The weight of each criterion was normalized if necessary. As the total weightage of all criteria exceeds the value 1, normalization was necessary. Example of finding the normalization for price criteria is as follows:

$$
0.044=0.044 \div 1.007
$$

From the normalized weight, the factors that affect customer satisfaction in the fast-food restaurant were then ranked.

Table 6 The Normalized Weight with Ranking.

\begin{tabular}{|c|c|}
\hline Criteria & Fuzzy weight \\
\hline Price & $(0.039,0.043,0.049)$ \\
\hline $\begin{array}{c}\text { Quality of } \\
\text { food }\end{array}$ & $(0.189,0.218,0.250)$ \\
\hline $\begin{array}{c}\text { Quality of } \\
\text { service }\end{array}$ & $(0.190,0.219,0.252)$ \\
\hline $\begin{array}{c}\text { Atmosphere of } \\
\text { restaurant }\end{array}$ & $(0.103,0.121,0.143)$ \\
\hline Promotion & $(0.101,0.123,0.148)$ \\
\hline $\begin{array}{c}\text { Customer } \\
\text { expectation }\end{array}$ & $(0.102,0.119,0.138)$ \\
\hline Brand & $(0.134,0.157,0.178)$ \\
\hline
\end{tabular}

The factors that affect customer satisfaction in a fast-food restaurant in Perlis the most are the quality of service, followed by quality of food, brand, promotion, the atmosphere of the restaurant, customer expectation, and lastly, price.

\section{CONCLUSION}

The factors that affect customer satisfaction in the fast-food restaurant were ranked according to the experts' decision by collecting information from the questionnaire distributed to them. From the results obtained, the quality of the service of the fast-food restaurant is the most significant key to secure customer satisfaction.

\section{ACKNOWLEDGMENTS}

The authors express gratitude to the fast-food restaurants, McDonald's (McD), Kentucky Fried Chicken (KFC), Pizza Hut, Domino's Pizza, Marrybrown, and Subway for their kind co-operation and encouragement, which help in the completion of this study. 


\section{REFERENCES}

Akhtar, N., \& Rehman, A. U. (2014). Factors Affecting Customer Satisfaction in Banking Sector of Pakistan. International Review of Managment and Business Research, 3(2), 1014-1025.

Dotoli, M., Epicoco, N., \& Falagario, M. (2020). Multi-Criteria Decision Making techniques for the management of public procurement tenders: A case study. Applied Soft Computing, 88, 106064. https://doi.org/10.1016/J.ASOC.2020.106064

Jovčić, S., Průša, P., Samson, J., \& Lazarević, D. (2019). a Fuzzy- Ahp Approach To Evaluate the Criteria of Third -Party Logistics (3Pl) Service Provider. International Journal for Traffic and Transport Engineering, 9(3), 280-289.

Karki, D., \& Panthi, A. (2018). How Food Quality, Price, Ambiance and Service Quality Effects Customer Satisfaction: A study on Nepalese Restaurants in Finland. 1-68.

Khan, S., Hussain, S. M., \& Yaqoob, F. (2013). Determinants of Customer Satisfaction in Fast Food Industry A Study of Fast Food Restaurants Peshawar Pakistan. Studia Commercialia Bratislavensia, 6(21), 56-65.

Kecek, G., \& Gurdal, H., (2016). Determination of Preference Ranking of Fast Food Companies with Analytic Hierarchy Process: An Application in Dumplupinar University. European Journal of Business and Management,8(5), 28-34.

Praščević, N. \& Praščević, Ž. (2016). Application of fuzzy AHP method based on eigenvalues for decision making in construction industry. Tehnički vjesnik, 23 (1), 57-64. https://doi.org/10.17559/TV20140212113942.

Putra, M. S. D., Andryana, S., Fauziah, \& Gunaryati, A. (2018). Fuzzy analytical hierarchy process method to determine the quality of gemstones. Advances in Fuzzy Systems, 2018.

Qin, H., \& Prybutok, V. R. (2009). Service quality, customer satisfaction, and behavioral intentions in fastfood restaurants. International Journal of Quality and Service Sciences, 1(1), 78-95.

Velazquez, M. A., Claudio, D., \& Ravindran, A. R. (2010). Experiments in multiple criteria selection problems with multiple decision makers. International Journal of Operational Research, 7(4), 413428. https://doi.org/10.1504/IJOR.2010.032419. 